\title{
Creep and shrinkage of high-strength self-compacting concrete: experimental and analytical analysis
}

\section{Farhad Aslani}

Centre for Built Infrastructure Research, School of Civil and Environmental Engineering, University of Technology Sydney, Sydney, Australia

\section{Lino Maia}

LABEST, Laboratory for the Concrete Technology and Structural Behaviour, Faculdade de Engenharia, Universidade do Porto, Porto, Portugal; Centro de Ciências Exatas e da Engenharia, Universidade da Madeira, Campus Universitário da Penteada, Funchal, Portugal

In the present paper, a numerical and experimental study about creep and shrinkage behavior of a high strength selfcompacting concrete is performed. Two new creep and shrinkage prediction models based on the comprehensive analysis on the available models of both conventional concrete and self-compacting concrete are proposed for high strength self-compacting concrete structures. In order to evaluate the predictability of the proposed models, an experimental program was carried out. A concrete which develops $60 \mathrm{MPa}$ within $24 \mathrm{~h}$ was used to obtain experimental results. Several specimens were loaded: (i) at different ages and (ii) with different stress-to-strength ratios. Deformation in non-loaded specimens was also measured to assess shrinkage. All specimens were kept under constant stress during at least 600 days in a climatic chamber with temperature and relative humidity of $20^{\circ} \mathrm{C}$ and $50 \%$, respectively. Results showed that the new models were able to predict deformations with good accuracy, although provided deformations overestimated slightly.

\section{Notation}

$a$ and $b$ $c$

$f_{\mathrm{c}}^{\prime}$

$f_{\mathrm{cm}}(t)$

$f_{\mathrm{c}, 28 \mathrm{~d}}^{\prime}$

$s^{\prime}$ and $n$

$T\left(\Delta t_{i}\right)$

$T_{0}$

$t$

$t_{0}$

$t_{0}, t^{\prime}$ and $t$

$V_{\mathrm{g}} / V_{\mathrm{g}, \lim }$

$V_{\mathrm{s}} / V_{\mathrm{m}}$

$V_{\mathrm{sf}} / V_{\mathrm{s}}$

$V_{\mathrm{w}} / V_{\mathrm{p}}$

w

$v / s$

$\alpha$

$\beta$ constants

cement

compressive strength

mean value of compressive strength at time $t$

compressive strength at the age of 28 days

parameters that have to be specifically calibrated

for each SCC concrete mix by using experimental results

the temperature $\left({ }^{\circ} \mathrm{C}\right)$ during the time period $\Delta t_{i}$

$1{ }^{\circ} \mathrm{C}$

temperature-adjusted concrete age

starting drying concrete age

effective age (days) of concrete at the beginning

of drying, at the beginning of loading and during

loading respectively

volume of gravel-to-volume limit of gravel ratio

volume of sand-to-volume of mortar ratio

volume of fine sand-to-volume of sand ratio

volume of water-to-volume of powder ratio

water

volume to surface ratio

coefficient representing the influence of the

cement type

represents time dependency of drying shrinkage $\gamma$

$\Delta t_{i}$

$\varepsilon_{\text {as }}^{\prime}\left(t, t_{0}\right) \quad$ autogenous shrinkage strain of concrete from the start of setting to age $t$

$\varepsilon_{\text {as } \infty}^{\prime} \quad$ final value of autogenous shrinkage strain

$\varepsilon_{\mathrm{bc}}^{\prime} \quad$ final value of basic creep strain per unit stress

$\varepsilon_{\mathrm{cc}}^{\prime}\left(t, t^{\prime}, t_{0}\right)$ creep strain

$\varepsilon_{\mathrm{cr}}^{\prime} \quad$ final value of creep strain per unit stress

$\varepsilon_{\mathrm{cs}}^{\prime}\left(t, t_{0}\right) \quad$ shrinkage strain of concrete from age to $t$

$\varepsilon_{\mathrm{dc}}^{\prime} \quad$ final value of drying creep strain per unit stress

$\varepsilon_{\mathrm{ds}}^{\prime}\left(t, t_{0}\right) \quad$ drying shrinkage strain of concrete from age to $t$

$\varepsilon_{\mathrm{ds} \rho}^{\prime} \quad$ final value of drying shrinkage strain

$\varepsilon_{\mathrm{ds} \infty}^{\prime} \quad$ final value of drying shrinkage

$\varepsilon_{\mathrm{sc}}^{\prime}\left(t, t_{0}\right) \quad$ shrinkage strain of concrete from age of $t_{0}$ to $t$

$\varepsilon_{\mathrm{sh}}^{\prime} \quad$ final value of shrinkage strain

$\eta \quad$ constant related to compressive strength and water content

$\kappa \quad$ conventional scalar damage index

$\mu, \lambda$ and $\alpha$ parameters to be obtained from a least square minimisation procedure

$\sigma_{\mathrm{cp}}^{\prime} \quad$ creep stress unit 


\section{Introduction}

Self-compacting concrete (SCC) basically consists of the same constituent materials as conventional concrete (CC) (cement, water, aggregates, admixtures and mineral additions), but the final composition of the mixture and its fresh properties are different. In comparison with CC, SCC contains larger quantities of mineral fillers, such as finely crushed limestone or fly ash, and in higher quantities of high-range water-reducing admixtures the maximum size of the coarse aggregate is smaller. These modifications in the composition of the mixture affect the behaviour of the concrete in its hardened state. Using SCC can lead to massive labour and cost savings. It is significant to estimate accurately the crucial mechanical properties of this structural material, including creep and shrinkage deformations, to arrive at a safe and economic analysis and design (Aslani and Nejadi, 2012a).

One critical property is creep of concrete. Creep depends on the characteristics of aggregate stiffness and texture, water/cement (w/c) ratio, volume of paste, volume of coarse aggregate, cement type, admixture type, curing method, ratio of volume to surface area, environmental conditions, magnitude of loads and age of loading. According to Neville (1996) mostly the hydrated cement paste experiences creep, whereas the aggregate is the only portion that resists against creep. Therefore, creep is highly dependent on the stiffness of the chosen aggregate and its proportion within the mixture (Neville, 1996). As a result, as creep mainly occurs in the cement paste, the main concern is that SCC may exhibit higher creep because of its high paste content.

Another essential mechanical parameter is the shrinkage of concrete. The overall shrinkage of concrete corresponds to a combination of several shrinkages: plastic shrinkage, autogenous shrinkage, drying shrinkage, thermal shrinkage and carbonation (chemical) shrinkage. In designing CC, shrinkage is frequently taken as drying shrinkage, which is the strain associated with the loss of moisture from the concrete under drying conditions because with a relatively high $\mathrm{w} / \mathrm{c}$ ratio (higher than 0.40 ) $\mathrm{CC}$ exhibits a relatively low autogenous shrinkage $<100 \times 10^{-6}$ (Aslani and Nejadi, 2012b). In contrast, the SCC used in the precast industry, namely for prestressed applications, typically has a low w/c ratio $(0 \cdot 32-0 \cdot 40)$. These relatively low $\mathrm{w} / \mathrm{c}$ ratios, coupled with a high content of binder lead to greater autogenous shrinkage. Such shrinkage increases and is notable in SCC because of the use of finely ground supplementary cementitious materials and fillers. Therefore, both drying and autogenous shrinkage deformations have to be considered in the structural detailing of reinforced concrete and prestressed concrete members (Khayat and Long, 2010).

Aware that SCC usually has a higher paste volume and/or higher sand-to-aggregate ratio to achieve high workability, several researchers have claimed relatively large creep and shrinkage of SCC for precast/prestressed concrete, resulting in larger prestress losses (Issa et al., 2005; Naito et al., 2006; Schindler et al., 2007; Suksawang et al., 2006). In fact, although mechanical properties of SCC are superior to those of CC, creep and shrinkage of SCC are significantly high (Issa et al., 2005). Among others, Naito et al. (2006) also found that SCC exhibits higher shrinkage and creep than $\mathrm{CC}$, which is probably attributable to the high fine aggregate and paste volume in the SCC.

However, Schindler et al. (2007) revealed that the shrinkage of SCC is similar to or less than that of CC. When the shrinkage of SCC is compared with that of CC at 112 days, the sand-toaggregate ratio effect is not significant for the shrinkage of SCC. The creep coefficients of SCC mixtures were also smaller than those of $\mathrm{CC}$ at all loading ages. This was attributed to the low $\mathrm{w} / \mathrm{c}$ ratio.

The different methodology followed to obtain SCC in different countries (Ouchi et al., 2003) and the limited number of studies concerning its long-term behaviour (Mazzotti and Ceccoli, 2009; Mazzotti et al., 2006; Persson, 2001, 2005; Poppe and De Schutter, 2001; Seng and Shima, 2005) make it still unclear if current international standards can also be applied successfully to SCC (Klug and Holschemaker, 2003; Landsberger and FernandezGomez, 2007; Vidal et al., 2005). Moreover, it has not even been assessed if long-term properties can be predicted with reference to conventional mechanical and physical parameters only (such as strength or w/c ratio), or if the adoption of parameters concerning the mix design is needed.

\section{Research significance}

It is vital to investigate whether all the assumed hypotheses used to design structures of $\mathrm{CC}$ about creep and shrinkage are also valid for high-strength SCC (HSSCC) structures. Thus, the objectives of this study are

(a) to review the accuracies of the CC creep and shrinkage prediction models proposed by international codes of practice, including AASHTO (2004, 2007), ACI (1992), AS (2009), CEB-FIB (2012), BSI (2004) and JSCE (2002)

(b) to review the accuracies of the SCC creep and shrinkage prediction models proposed by Cordoba (2007), Khayat and Long (2010), Larson (2006), and Poppe and De Schutter (2005)

(c) to propose a new prediction creep and shrinkage model based on the comprehensive analysis of the available models and the experimental results database of both the $\mathrm{CC}$ and the $\mathrm{SCC}$

(d) to verify the predictability of the proposed models on experimental results conducted in a mix composition previously used in the prefabrication of prestressed bridge girders, i.e. a HSSCC loaded at early ages.

\section{Numerical analysis}

Based on recent studies by Aslani and Nejadi (2011a, 2011b), the following procedures are used for comparing available CC creep and shrinkage models 
- establish an experimental database for creep and shrinkage results

- establish available creep and shrinkage prediction models database

compare creep and shrinkage models with SCC experimental results database

- propose SCC creep and shrinkage models based on the previous comparisons

- verify proposed SCC creep and shrinkage models with experimental results tests that have been done in this study.

\section{Creep and shrinkage experimental results database}

Tables 1 and 2 present a general summary of the creep and shrinkage concrete mixtures included in the database. The database comprises test results from 11 different investigations, with a total of $52 \mathrm{SCC}$ and $11 \mathrm{CC}$ mixtures for creep tests. Also, the database comprises test results from 14 different investigations, with a total of 165 different SCC mixtures and 21 CC mixtures for shrinkage tests. Tables 1 and 2 also include additional information regarding the applied stress to the creep specimens, age of concrete when shrinkage begins (days), final age of the concrete, relative humidity $(\mathrm{RH})$, type of the specimen, type of cement and filler.

\section{Creep and shrinkage models}

This paper also assesses the accuracy of seven commonly used international code-type models that are used to predict creep and shrinkage strains. These empirically-based models, which vary widely in their techniques, require certain intrinsic and/or extrinsic variables, such as mix proportions, material properties and age of loading, as input. The models considered are listed in Table 3, which also shows the factors encountered by each model. In this study the accuracy of the creep and shrinkage prediction models proposed by international codes of practice, including AASHTO (2004, 2007), ACI (1992), AS (2009), CEB-FIB (2012), BSI (2004) and JSCE (2002), are compared with the actual measured creep and shrinkage strains.

As shown in Table 4, the AASHTO (2004, 2007), BSI (2004) and JSCE (2002) models provided better prediction of creep data for CC mixture in the experimental database with a coefficient of correlation factor $\left(R^{2}\right)$ of $0 \cdot 90,0 \cdot 89,0 \cdot 89$ and 0.86 compared with other models. Also, as shown in Table 4, for the SCC mixture in the experimental database, the AASHTO (2004), ACI (1992) and JSCE (2002) models provided better prediction of creep data with a coefficient of correlation factor $\left(R^{2}\right)$ of $0.87,0.87$ and 0.84 compared with other models.

AASHTO (2004), ACI (1992) and JSCE (2002) CC creep models that have conservative predictions for SCC mixtures in the database are different in the certain intrinsic and/or extrinsic variables. As mentioned in Table 3, the AASHTO (2004) creep model does not have any intrinsic factors, but the JSCE (2002) and ACI (1992) creep models have a good consideration of both intrinsic variables (i.e. aggregate type, aggregates/cement ratio, air content, cement content, cement type, concrete density, fine/ total aggregate ratio, slump, w/c ratio and water content) and extrinsic variables (i.e. age at the first loading, age of sample, applied stress, characteristic strength at loading, cross-section shape, curing conditions, compressive strength at 28 days, duration of load, effective thickness, elastic modulus at age of loading, elastic modulus at 28 days, $\mathrm{RH}$, temperature and time drying commences). The modified composition of SCC in comparison with $\mathrm{CC}$ influences the creep behaviour of the concrete. Therefore, it is important to include some important variables that have an impact on this behaviour. By considering these variables, the JSCE (2002) creep model has good intrinsic and extrinsic variables.

As show in Table 5, for CC mixture in the experimental database, the AASHTO (2007) and JSCE (2002) models provided a better prediction of drying shrinkage data with a coefficient of correlation factor $\left(R^{2}\right)$ of 0.88 and 0.84 compared with other models. Also, as shown in Table 5, the AASHTO (2007), AS (2009) and JSCE (2002) models provided a better prediction of SCC mixture in the experimental database drying shrinkage data with a coefficient of correlation factor $\left(R^{2}\right)$ of $0 \cdot 86,0 \cdot 83$ and 0.80 compared with other models.

The CC shrinkage models of AASHTO (2007) and JSCE (2002) that have conservative predictions for SCC mixtures in the database are different in the certain intrinsic and/or extrinsic variables. As mentioned in Table 3, the AASHTO (2007) shrinkage model does not have any intrinsic factors, but the JSCE (2002) shrinkage model has a good consideration of both intrinsic and extrinsic variables. When compared with the $\mathrm{CC}$, the modified composition of SCC influences the shrinkage behaviour of concrete. Therefore, it is important to involve some important variables that have an impact on this behaviour. By considering these variables, the JSCE (2002) shrinkage model has good intrinsic and extrinsic variables.

\section{Proposed creep model}

The comparison of the different models and the experimental database shows that the ACI (1992), JSCE (2002) and AASHTO (2004) models have conservative creep coefficient predictions. In this study, based on required certain intrinsic and/or extrinsic variables for SCC, the JSCE (2002) creep model gives a good approximation of the creep coefficient. Therefore, with the JSCE (2002) creep model as a basis, an attempt is made to formulate some suggestions to include the cement-to-powder $(\mathrm{c} / \mathrm{p})$ ratio into the formulas in order to obtain a better prediction of the time-dependent deformations of normal strength and high strength of SCC. These results are shown in Equations 1-10.

1. For the normal-strength SCC with range of applicability (see the denomination of the parameters in the Notation) 


\begin{tabular}{|c|c|c|c|c|c|c|c|c|}
\hline Reference & $\begin{array}{l}\text { No. of SCC } \\
\text { mixtures }\end{array}$ & $\begin{array}{l}\text { No. of CC } \\
\text { mixtures }\end{array}$ & $\begin{array}{l}\text { Applied stress to the } \\
\text { creep specimens }\end{array}$ & $\begin{array}{l}\text { Final age of } \\
\text { concrete: } \\
\text { days }\end{array}$ & $\mathrm{RH}: \%$ & Type of specimen: mm & Type of cement & Type of filler \\
\hline Chopin et al. (2003) & 5 & 1 & $\begin{array}{l}40 \% \text { or } 60 \% \text { of the } \\
\text { compressive strength at } \\
28 \text { days }\end{array}$ & 365 & 50 & Cylinder $(90 \times 280)$ & CEM I & Limestone \\
\hline $\begin{array}{l}\text { Poppe and De Schutter } \\
\text { (2005) }\end{array}$ & 6 & 0 & $\begin{array}{l}1 / 3 \text { of the compressive } \\
\text { strength at } 28 \text { days }\end{array}$ & 1400 & 60 & Prism $(150 \times 150 \times 500)$ & $\begin{array}{l}\text { CEM I } 42 \cdot 5 \mathrm{R}, \\
\text { CEM I } 52 \cdot 5\end{array}$ & Limestone \\
\hline Horta (2005) & 6 & 0 & $\begin{array}{l}40 \% \text { of the compressive } \\
\text { strength at } 28 \text { days }\end{array}$ & 70,200 & 50 & Cylinder $(150 \times 300)$ & CEM I, CEM III & Fly ash and GGBFS \\
\hline Larson (2006) & 1 & 0 & $\begin{array}{l}40 \% \text { of the compressive } \\
\text { strength at } 28 \text { days }\end{array}$ & 520 & 50 & $\begin{array}{l}\text { Prism } \\
(101.6 \times 101.6 \times 609.6) \\
\text { and cylinder } \\
(114.3 \times 609.6)\end{array}$ & CEM III & Limestone \\
\hline Turcry et al. (2006) & 3 & 3 & $\begin{array}{l}20 \% \text { of the compressive } \\
\text { strength at } 7 \text { days }\end{array}$ & 65,100 & 50 & Cylinder $(110 \times 200)$ & $\begin{array}{l}\text { CEM I } 52 \cdot 5 \\
\text { CEM || } 42 \cdot 5\end{array}$ & Limestone \\
\hline Cordoba (2007) & 4 & 1 & $\begin{array}{l}30 \% \text { of the compressive } \\
\text { strength at } 28 \text { days }\end{array}$ & 365 & 50 & $\begin{array}{l}\text { Cylinder }(101.6 \times 203.2) \\
(101.6 \times 1057.8)\end{array}$ & CEM I/II & Fly ash and GGBFS \\
\hline Heirman et al. (2008) & 7 & 1 & $\begin{array}{l} \pm 1 / 3 \text { of the compressive } \\
\text { strength at } 28 \text { days }\end{array}$ & 70 & 60 & Cylinder $(120 \times 300)$ & $\begin{array}{l}\text { CEM I } 42 \cdot 5 \mathrm{R}, \\
\text { CEM III/A } 42 \cdot 5 \mathrm{~N} \\
\text { LA }\end{array}$ & Limestone \\
\hline $\begin{array}{l}\text { Oliva and Cramer } \\
\text { (2008) }\end{array}$ & 11 & 4 & $\begin{array}{l}40 \% \text { of the compressive } \\
\text { strength at } 28 \text { days }\end{array}$ & 495 & 50 & Cylinder $(152.4 \times 213.6)$ & CEM I & GGBFS \\
\hline Kim (2008) & 4 & 4 & $\begin{array}{l}\text { Changeable for each } \\
\text { mixture }\end{array}$ & 150 & 50 & Cylinder $(100 \times 200)$ & CEM III & Fly ash and limestone \\
\hline Zheng et al. (2009) & 7 & 1 & $\begin{array}{l}30 \% \text { of the compressive } \\
\text { strength at loading days }\end{array}$ & 150 & 60 & Prism $(100 \times 100 \times 400)$ & CEM I & Fly ash \\
\hline $\begin{array}{l}\text { Loser and Leemann } \\
\text { (2009) }\end{array}$ & 1 & 1 & $\begin{array}{l}\text { Changeable for each } \\
\text { mixture }\end{array}$ & 91 & 70 & Prism $(120 \times 120 \times 360)$ & $\begin{array}{l}\text { CEM I } 42 \cdot 5 \mathrm{~N}, \\
\text { CEM II/A-LL } \\
45 \cdot 2 \mathrm{~N}\end{array}$ & Fly ash and limestone \\
\hline Total of 71 mixtures & 55 & 16 & & & & & & \\
\hline
\end{tabular}




\begin{tabular}{|c|c|c|c|c|c|c|c|c|}
\hline Reference & $\begin{array}{l}\text { No. of SCC } \\
\text { mixtures }\end{array}$ & $\begin{array}{l}\text { No. of CC } \\
\text { mixtures }\end{array}$ & $\begin{array}{c}\text { Age of } \\
\text { concrete } \\
\text { when } \\
\text { shrinkage } \\
\text { begins: days }\end{array}$ & $\begin{array}{l}\text { Final age of } \\
\text { concrete: days }\end{array}$ & $\mathrm{RH}: \%$ & Type of specimen (mm) & Type of cement & Type of filler \\
\hline Chopin et al. (2003) & 5 & 1 & 1 & 365 & 50 & Cylinder $(90 \times 280)$ & CEM I & Limestone \\
\hline $\begin{array}{l}\text { Poppe and De Schutter } \\
\text { (2005) }\end{array}$ & 4 & 0 & 1 & 1400 & 60 & $\begin{array}{l}\text { Prism } \\
(150 \times 150 \times 500)\end{array}$ & CEM I 42, 5 R, CEM I 52,5 & Limestone \\
\hline Larson (2006) & 1 & 0 & 1 & 520 & 50 & $\begin{array}{l}\text { Prism }(101.6 \times 101.6 \\
\times 609.6) \text { and cylinder } \\
(114.3 \times 609.6)\end{array}$ & CEM III & Limestone \\
\hline Turcry et al. (2006) & 3 & 3 & 1 & $120,150,210$ & 50 & Prism $(70 \times 70 \times 280)$ & CEM I 52.5, CEM $\| 42 \cdot 5$ & Limestone \\
\hline Cordoba (2007) & 4 & 1 & 1 & 365 & 50 & $\begin{array}{l}\text { Cylinder } \\
(101.6 \times 203.2) \\
(101.6 \times 1057.8)\end{array}$ & CEM I/II & Fly ash and GGBFS \\
\hline Heirman et al. (2008) & 7 & 1 & 1 & 98 & 60 & Cylinder $(120 \times 300)$ & $\begin{array}{l}\text { CEM I } 42 \cdot 5 \text { R, CEM III/A } 42.5 \mathrm{~N} \\
\text { LA }\end{array}$ & Jimestone \\
\hline Bhattacharya (2008) & 6 & 2 & 1 & 90 & 50 & $\begin{array}{l}\text { Prism } \\
(76.2 \times 76.2 \times 311 \cdot 2)\end{array}$ & CEM I & $\begin{array}{l}\text { Limestone, silica } \\
\text { fume and slag }\end{array}$ \\
\hline Oliva and Cramer (2008) & 11 & 4 & 1 & 350,495 & 50 & $\begin{array}{l}\text { Prism }(101.6 \times 101.6 \\
\times 285.75)\end{array}$ & CEM I & GGBFS \\
\hline $\begin{array}{l}\text { Hwang and Khayat } \\
(2010)\end{array}$ & 10 & 2 & 1 & 56 & 50 & Prism $(75 \times 75 \times 285)$ & $\begin{array}{l}\text { CSA type Gub-F/SF, } \\
\text { Gub-S/SF and quaternary } \\
\text { blended cement }\end{array}$ & $\begin{array}{l}\text { Fly ash and } \\
\text { limestone }\end{array}$ \\
\hline Ma et al. (2009) & 16 & 0 & 1 & 120,150 & 60 & $\begin{array}{l}\text { Prism } \\
(100 \times 100 \times 515)\end{array}$ & CEM I & Fly ash \\
\hline $\begin{array}{l}\text { Loser and Leemann } \\
\text { (2009) }\end{array}$ & 13 & 3 & 1 & 91 & 70 & $\begin{array}{l}\text { Prism } \\
(120 \times 120 \times 360)\end{array}$ & $\begin{array}{l}\text { CEM I } 42 \cdot 5 \mathrm{~N}, \text { CEM II/A-LL } \\
45 \cdot 2 \mathrm{~N}\end{array}$ & $\begin{array}{l}\text { Fly ash and silica } \\
\text { fume }\end{array}$ \\
\hline Güneyisi et al. (2010) & 63 & 2 & 1 & 50 & 50 & Prism $(70 \times 70 \times 280)$ & CEM I & $\begin{array}{l}\text { Fly ash, GGBFS, silica } \\
\text { fume and } \\
\text { metakaolin }\end{array}$ \\
\hline Khayat and Long (2010) & 16 & 2 & 1 & 300 & 50 & Cylinder $(150 \times 300)$ & $\begin{array}{l}\text { MS and HE (similar to ASTM } \\
\text { C150 Type I/II and Type III) }\end{array}$ & Fly ash \\
\hline Total of 186 mixtures & 165 & 21 & & & & & & \\
\hline
\end{tabular}




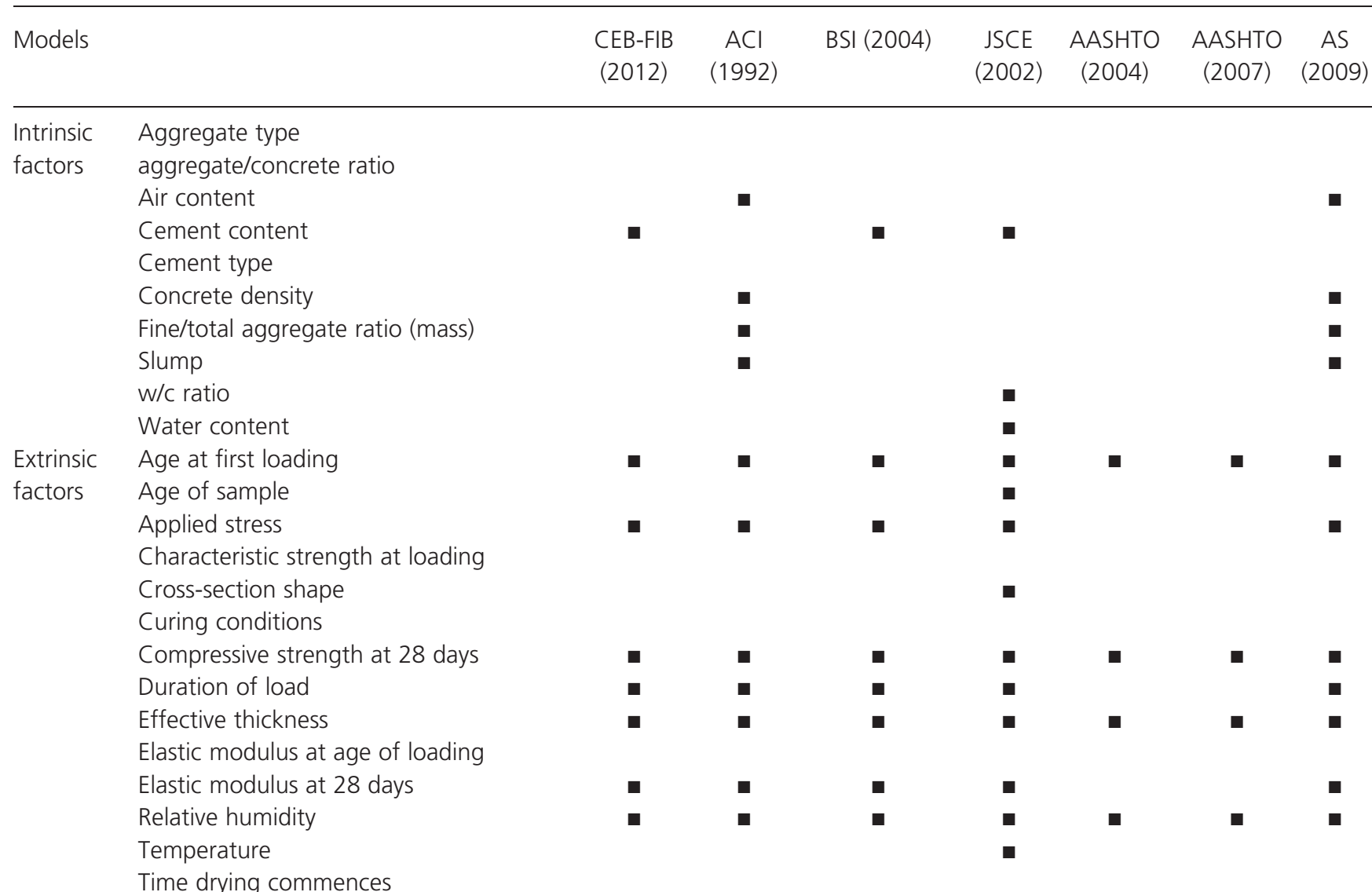

Table 3. Summary of factors accounted for by different prediction models

\begin{tabular}{|c|c|c|c|c|c|}
\hline Creep prediction models & $\begin{array}{l}C C \\
R^{2}\end{array}$ & $\begin{array}{c}\mathrm{SCC} \\
R^{2}\end{array}$ & Shrinkage prediction models & $\begin{array}{l}C C \\
R^{2}\end{array}$ & $\begin{array}{c}\mathrm{SCC} \\
R^{2}\end{array}$ \\
\hline CEB-FIB (2012) & 0.41 & $0 \cdot 58$ & CEB-FIB (2012) & $0 \cdot 70$ & 0.57 \\
\hline $\mathrm{ACl}(1992)$ & 0.79 & 0.84 & $\mathrm{ACl}(1992)$ & 0.62 & 0.66 \\
\hline BSI (2004) & 0.89 & $0 \cdot 80$ & BSI (2004) & 0.72 & 0.55 \\
\hline JSCE (2002) & 0.89 & 0.87 & JSCE (2002) & 0.84 & 0.83 \\
\hline AASHTO (2004) & 0.86 & 0.87 & AASHTO (2004) & 0.42 & 0.47 \\
\hline AASHTO (2007) & 0.90 & $0 \cdot 80$ & AASHTO (2007) & 0.88 & 0.86 \\
\hline AS (2009) & 0.70 & $0 \cdot 75$ & AS (2009) & 0.65 & 0.80 \\
\hline \multicolumn{3}{|c|}{$\begin{array}{l}\text { Table 4. Coefficient of correlation factor }\left(R^{2}\right) \text { of creep prediction } \\
\text { models for conventional concrete (CC) and self-compacting } \\
\text { concrete (SCC) }\end{array}$} & \multicolumn{3}{|c|}{$\begin{array}{l}\text { Table 5. Coefficient of correlation factor }\left(\mathrm{R}^{2}\right) \text { of shrinkage } \\
\text { prediction models for conventional concrete }(\mathrm{CC}) \text { and } \\
\text { self-compacting concrete }(\mathrm{SCC})\end{array}$} \\
\hline
\end{tabular}

$45 \% \leqslant \mathrm{RH} \leqslant 80 \%$

$120 \mathrm{~kg} / \mathrm{m}^{3} \leqslant w \leqslant 230 \mathrm{~kg} / \mathrm{m}^{3}$
$100 \mathrm{~mm} \leqslant v / s \leqslant 300 \mathrm{~mm}$

$0 \cdot 30 \leqslant w / c \leqslant 0 \cdot 65$ 


$$
f_{\mathrm{c}, 28 \mathrm{~d}}^{\prime} \leqslant 55 \mathrm{MPa}
$$

$$
260 \mathrm{~kg} / \mathrm{m}^{3} \leqslant c \leqslant 500 \mathrm{~kg} / \mathrm{m}^{3}
$$

1.

$$
\begin{aligned}
\varepsilon_{\mathrm{cc}}^{\prime}\left(t, t^{\prime}, t_{0}\right)= & \sigma_{\mathrm{cp}}^{\prime} \\
& \times \varepsilon_{\mathrm{cr}}^{\prime}\left[1-\exp \left\{-0 \cdot 09\left(t-t^{\prime}\right)^{0.54}\right\}\right] \\
& \times(0 \cdot 015+1.35(c / p))^{-1}
\end{aligned}
$$

for $c / p<0.65$

$$
\begin{aligned}
\varepsilon_{\mathrm{cc}}^{\prime}\left(t, t^{\prime}, t_{0}\right)= & \sigma_{\mathrm{cp}}^{\prime} \times \varepsilon_{\mathrm{cr}}^{\prime}\left[1-\exp \left\{-0.09\left(t-t^{\prime}\right)^{0.54}\right\}\right] \\
& \times(0.015+1.05(c / p))^{-1} \\
& \text { for } c / p \geqslant 0.65
\end{aligned}
$$$$
2 .
$$

$$
\sigma_{\mathrm{cp}}^{\prime}=\frac{\mu+\lambda \cdot \sigma\left(t, t_{0}\right)^{\alpha}}{1-\kappa}
$$

\section{3. non-linear creep amplification function}

where $\mu, \lambda$ and $\alpha$ are additional parameters to be obtained from a least square minimisation procedure starting from experimental data (Mazzotti and Ceccoli, 2009) $\mu=0.90$, $\lambda=1 \cdot 80, \alpha=2 \cdot 10$; moreover, the stress function $\sigma\left(t, t_{0}\right)$ is the actual stress/strength ratio, being

$$
\text { 4. } \sigma\left(t, t_{0}\right)=\frac{\sigma\left(t_{0}\right)}{f_{\mathrm{cm}}(t)}
$$

in the case of constant applied load. In Equation 3, the numerator and denominator indicate the effect of sustained load and the effect of a damage level owing to instantaneous loading. The law $f_{\mathrm{cm}}(t)$ representing the evolution with time of compression strength has been defined by modifying the MC90 proposal according to the expression

$$
\text { 5. } f_{\mathrm{cm}}(t)=f_{\mathrm{c}, 28}^{\prime} \cdot \exp \left[s^{\prime}\left(1-\left(\frac{28}{t}\right)^{n}\right)\right]
$$

where parameters $s^{\prime}$ and $n$ have been specifically calibrated for each SCC concrete mix by using experimental results previously described (see Table 3 ). According to the available data, parameters $s^{\prime}$ and $n$ range from 0.2 to 0.6 and 0.28 to
0.35 respectively (Mazzotti and Ceccoli, 2009). The adoption of function $\sigma\left(t, t_{0}\right)$ allows for the variable rate of increase of mechanical properties to be taken into account, which is particularly important for concretes loaded at early ages. Finally, the non-linear behaviour during the load application has been introduced in Equation 3 according to the conventional scalar damage index $\kappa=1-E / E_{0}$, in which $E$ is the secant stiffness at the end of loading and $E_{0}$ is the initial tangent stiffness. Usually, damage index $\kappa$ is about $0 \cdot 10-0 \cdot 15$ or $0 \cdot 22-0.35$ for low $\left(0.35 f_{\mathrm{cm}}(t)\right)$ or medium $\left(0.55 f_{\mathrm{cm}}(t)\right)$ applied stress levels respectively

6. $\varepsilon_{\mathrm{cr}}^{\prime}=\varepsilon_{\mathrm{bc}}^{\prime}+\varepsilon_{\mathrm{dc}}^{\prime}$

7. $\varepsilon_{\mathrm{bc}}^{\prime}=\left[17 \cdot 5(c+w)^{2 \cdot 0}(w / c)^{2 \cdot 4}\left\{\ln \left(t^{\prime}\right)\right\}^{-0 \cdot 67}\right] \times 10^{-10}$

$$
\begin{aligned}
\varepsilon_{\mathrm{dc}}^{\prime}= & {\left[4500(w / c)^{4 \cdot 2}(c+w)^{1 \cdot 4}\left[\ln \left(\frac{v / s}{10}\right)\right]^{-2 \cdot 2}\right.} \\
& \left.\times\left\{1-\frac{\mathrm{RH}}{100}\right\}^{0 \cdot 36} t_{0}^{-0 \cdot 30}\right] \times 10^{-10}
\end{aligned}
$$

2. For the HS SCC with range of applicability by using Equations 3-5

$$
45 \% \leqslant \mathrm{RH} \leqslant 90 \%
$$

$120 \mathrm{~kg} / \mathrm{m}^{3} \leqslant w \leqslant 230 \mathrm{~kg} / \mathrm{m}^{3}$

$100 \mathrm{~mm} \leqslant v / s \leqslant 300 \mathrm{~mm}$

$0 \cdot 30 \leqslant w / c \leqslant 0 \cdot 65$

$$
55 \leqslant f_{\mathrm{c}, 28 \mathrm{~d}}^{\prime} \leqslant 100 \mathrm{MPa}
$$

$$
\begin{aligned}
\varepsilon_{\mathrm{cc}}^{\prime}\left(t, t^{\prime}, t_{0}\right)=\sigma_{\mathrm{cp}}^{\prime} \\
\times\left[\frac{4 w(1-\mathrm{RH} / 100)+350}{12+f_{\mathrm{c}}^{\prime}\left(t^{\prime}\right)} \ln \left(t-t^{\prime}+1\right)\right] \\
\text { 9. } \quad \times\left(10 \times(c / p)^{0.678}\right) \text { for } c / p<0.65
\end{aligned}
$$




$$
\begin{aligned}
& \varepsilon_{\mathrm{cc}}^{\prime}\left(t, t^{\prime}, t_{0}\right)=\sigma_{\mathrm{cp}}^{\prime} \\
& \times\left[\frac{4 w(1-\mathrm{RH} / 100)+350}{12+f_{\mathrm{c}}^{\prime}\left(t^{\prime}\right)} \ln \left(t-t^{\prime}+1\right)\right] \\
10 . & \times\left(13 \times(c / p)^{0.701}\right) \text { for } c / p \geqslant 0.65
\end{aligned}
$$

where for $t_{0}, t^{\prime}$ and $t$ are replaced by

$$
t=\sum_{i=1}^{n} \Delta t_{i} \exp \left[13 \cdot 65-\frac{4000}{273+T\left(\Delta t_{i}\right) / T_{0}}\right]
$$

\section{Proposed shrinkage model}

The comparison of the different models and the experimental database shows that the AASHTO (2004), ACI (1992) and JSCE (2002) models have conservative drying shrinkage predictions. In this study, based on required certain intrinsic and/or extrinsic variables for SCC, the JSCE (2002) drying shrinkage model gives the best approximation of the drying shrinkage strain. Therefore, with the JSCE (2002) model as a basis, an attempt is made to formulate some suggestions to include the $\mathrm{c} / \mathrm{p}$ ratio into the formulas in order to obtain a better prediction of the timedependent deformations of normal strength and high strength of SCC. These results are shown in Equations 11-17.

For normal-strength SCC (with range of applicability same as creep proposed model)

11. $\varepsilon_{\mathrm{cs}}^{\prime}\left(t, t_{0}\right)=\varepsilon_{\mathrm{sh}}^{\prime}\left[1-\exp \left\{-0 \cdot 1\left(t-t_{0}\right)^{(-2 \cdot 4(c / p)+2 \cdot 3)}\right\}\right]$

$$
\begin{aligned}
\varepsilon_{\mathrm{sh}}^{\prime}= & {\left[-50+78\left\{1-\exp \left(\frac{\mathrm{RH}}{100}\right)\right\}+38 \cdot 3 \ln w\right.} \\
& \left.-0.92 \ln \left(\frac{w}{c}\right)-5\left[\ln \left(\frac{v / s}{10}\right)\right]^{2}\right] \times\left(10^{-5}\right)
\end{aligned}
$$

12.

$$
\text { for } c / p<0.65
$$

For the HS SCC with range of applicability (with range of applicability same as creep proposed model)

13. $\varepsilon_{\mathrm{cs}}^{\prime}\left(t, t_{0}\right)=\varepsilon_{\mathrm{ds}}^{\prime}\left(t, t_{0}\right)+\varepsilon_{\mathrm{as}}^{\prime}\left(t, t_{0}\right)$

14. $\varepsilon_{\mathrm{ds}}^{\prime}\left(t, t_{0}\right)=\frac{\varepsilon_{\mathrm{ds} \infty}^{\prime}\left(t-t_{0}\right)}{\beta+\left(t-t_{0}\right)}$
15. $\varepsilon_{\mathrm{ds} \infty}^{\prime}=\frac{\varepsilon_{\mathrm{ds} \rho}^{\prime}}{\eta t_{0}}\left(\times 10^{-6}\right)$

$$
\begin{aligned}
\varepsilon_{\mathrm{ds} \rho}^{\prime}= & {\left[\frac{\alpha(1-\mathrm{RH} / 100) w}{1+110 \exp \left\{-\frac{400}{f_{\mathrm{c}, 28 \mathrm{~d}}^{\prime}}\right\}}\right] } \\
& \times(0.015+1.35(c / p))^{-1} \\
& \text { for } c / p<0.65
\end{aligned}
$$

16.

$$
\begin{aligned}
\varepsilon_{\mathrm{ds} \rho}^{\prime}= & {\left[\frac{\alpha(1-\mathrm{RH} / 100) w}{1+110 \exp \left\{-\frac{410}{f_{\mathrm{c}, 28 \mathrm{~d}}^{\prime}}\right\}}\right] } \\
& \times(0.015+1.05(c / p))^{-1} \\
\text { 17. } \quad & \text { for } c / p \geqslant 0.65
\end{aligned}
$$

with

$$
\beta=\frac{4 w \sqrt{v / s}}{100+0 \cdot 7 t_{0}},
$$

$\eta=\left[15 \exp \left(0.007 f_{\mathrm{c}}^{\prime}(28)\right)+0 \cdot 25 w\right] \times 10^{-4}$,

$$
\varepsilon_{\mathrm{as}}^{\prime}\left(t, t_{0}\right)=\varepsilon_{\mathrm{as}}^{\prime}(t)-\varepsilon_{\mathrm{as}}^{\prime}\left(t_{0}\right),
$$

$\varepsilon_{\mathrm{as}}^{\prime}(t)=\gamma \varepsilon_{\mathrm{as} \infty}^{\prime}\left[1-\exp \left\{-a\left(t-t_{\mathrm{s}}\right)^{b}\right\}\right] \times 10^{-6}$,

$$
\varepsilon_{\mathrm{as} \infty}^{\prime}=3070 \exp \{-7 \cdot 2(w / c)\},
$$

$\alpha=11$ for normal and low heat cement or $\alpha=15$ for high early strength cement.

where for $t_{0}, t^{\prime}$ and $t$ are replaced by the temperature-adjusted concrete age and $\gamma$ is a coefficient representing the influence of the cement and admixtures type (may be 1 when only ordinary Portland cement is used). The variations of $a$ and $b$ constants with $\mathrm{w} / \mathrm{c}$ ratio are given in Table 6 . 


\begin{tabular}{lll}
$w / c$ & $a$ & $b$ \\
\hline 0.20 & 1.2 & 0.4 \\
0.23 & 1.5 & 0.4 \\
0.30 & 0.6 & 0.5 \\
0.40 & 0.1 & 0.7 \\
$\geqslant 0.50$ & 0.03 & 0.8
\end{tabular}

Table 6. Variations of $a$ and $b$ constants with water/cement (w/c) ratio

\section{Experimental programme}

In order to validate the proposed models, an experimental programme with shrinkage and creep tests was carried out in a laboratory. A mix composition previously used in the prefabrication of prestressed bridge girders was used. Bearing aware that in precast/prestress industries it is necessary to apply prestress as soon as possible in order to reduce the time of each production cycle, the concrete used is a SCC that reaches a compressive strength higher than $60 \mathrm{MPa}$ at the age of $24 \mathrm{~h}$. As a consequence, loading could be applied at early ages. In order to verify the predictability of the proposed models in a HSSCC loaded at early ages, in this experimental work specimens were loaded at the ages of $12 \mathrm{~h}, 16 \mathrm{~h}, 20 \mathrm{~h}, 24 \mathrm{~h}, 48 \mathrm{~h}$ and $72 \mathrm{~h}$.

\section{Materials and mix proportions}

Cement CEM I 42.5R (BSI, 2000a) with specific gravity of $3 \cdot 10$ and limestone filler with a specific gravity of 2.70 were used. A polycarboxylate type superplasticiser was used, having a specific gravity of 1.08 and $40.0 \%$ solid content. The aggregates were dried, and the specific gravities of the coarse aggregate, fine sand and coarse sand were $2 \cdot 68,2 \cdot 63$ and $2 \cdot 62$, and absorption values were $1.40 \%, 0.20 \%$ and $0.40 \%$, respectively, according to $\mathrm{EN}$ 1097-6:2000 (BSI, 2000b). The bulk density of the compacted gravel was 1.38. The water content was recalculated owing to water included in the superplasticiser and the water required to saturate the aggregates.

The constituent materials used and the corresponding mix proportions are reported in Table 7 . Note that the w/c ratio was $0 \cdot 32$, superplasticiser-to-powder ratio was $0 \cdot 80 \%$, volume of water-tovolume of powder ratio $\left(V_{\mathrm{w}} / V_{\mathrm{p}}\right)$ was 0.64 , volume of sandto-volume of mortar ratio $\left(V_{\mathrm{s}} / V_{\mathrm{m}}\right)$ was $0 \cdot 48$, volume of fine sand-to-volume of sand ratio $\left(V_{\mathrm{sf}} / V_{\mathrm{s}}\right)$ was 0.50 and volume of gravel-to-volume limit of gravel ratio $\left(V_{\mathrm{g}} / V_{\mathrm{g}, \mathrm{lim}}\right)$ was 0.65.

\section{Mixing, fresh testing and casting}

Several batches of 571 were prepared using a mixer with a vertical axis according to the following sequence

mixing aggregates and $15 \%$ of total water during $2.5 \mathrm{~min}$

stop mixing for $2.5 \mathrm{~min}$

- adding cement, filler, remaining water and superplasticiser and mixing for $5 \mathrm{~min}$
Material denomination: $\mathrm{kg}$

CEM I 42.5R (Portland)

400

Limestone filler

192

Sika viscocrete $20 \mathrm{HE}$

Natural fine siliceous sand

Natural coarse siliceous sand

Crushed limestone (washed gravel)

852

Tap water (total)

Table 7. Mix compositions per cubic meter

stop mixing for 1 min (cleaning mixer paddles)

mixing for $3 \mathrm{~min}$

- evaluation of the self-compacting properties and casting.

Immediately after mixing was finished, self-compacting properties were evaluated: the slump flow, the V-funnel, the L-box and the segregation tests were carried out according to the European guidelines for self-compacting concrete (EFNARC, 2005). All specimens were cast within 15 min after mixing was finished. After casting was finished, specimens were carefully moved in order to be stored up to the demoulding time in a temperature and $\mathrm{RH}$ controlled room $\left(20 \pm 0 \cdot 3^{\circ} \mathrm{C}\right.$ and $50 \pm 3 \%$ respectively). All tests were performed using cylinder specimens: specimens with $150 \mathrm{~mm}$ diameter and $300 \mathrm{~mm}$ height for compressive strength and elastic modulus tests; specimens with $141 \mathrm{~mm}$ diameter and $500 \mathrm{~mm}$ height for deformation measurements. In order to eliminate the effect of the specimens' surface roughness on the uniaxiality, the top and bottom faces of all specimens were smoothed just after demoulding. A thermocouple was located nearly at the centre of two specimens and to record the temperature over a period of $70 \mathrm{~h}$ to allow for maturity corrections.

\section{Deformation measurements}

The creep tests were carried out by applying a uniaxial load in two superposed specimens with a flat hydraulic jack, which was able to keep the stress constant throughout the test. Measurements were manually acquired by using a digital extensometer. Each specimen had eight pins divided per four generatrices rotated $90^{\circ}$ to each other. Three readings per generatrix were taken (the base of measuring was $200 \mathrm{~mm}$ ), and the specimen deformation calculated using the average of the four generatrices.

The loads corresponding to $20 \%, 30 \%$ and $40 \%$ of the stress-tostrength ratio (at the age of loading) were kept constant for at least 600 days. The first measurement was taken immediately before loading and the second one immediately after loading. In order to evaluate shrinkage deformations, two non-loaded specimens per age of loading were also measured.

\section{Concrete fresh and mechanical properties}

All the batches produced presented similar self-compactability and pertained to classes SF3, VS2/VF2, PA2 and SR2 (EFNARC, 
2005). The following results were observed: diameter for slump flow was $803 \pm 9.7 \mathrm{~mm}$; time for V-funnel test was $18.43 \pm 1.06 \mathrm{~s}$; ratio for L-box test was $0.94 \pm 0.04$; and the segregation was $5 \cdot 9 \pm 2 \cdot 5 \%$

The evolutions of the elastic modulus and the compressive strength of measured are summarised in Table 8. Bearing in mind that the mix composition was previously used in the prefabrication of prestressed bridge girders, as expected the concrete strength increased very quickly at early ages reaching almost $50 \mathrm{MPa}$ at the age of $12 \mathrm{~h}$ and more than $60 \mathrm{MPa}$ at $24 \mathrm{~h}$. Then, it continued to increase, but at lower rates, reaching nearly $70 \mathrm{MPa}$ at $72 \mathrm{~h}$ and $90 \mathrm{MPa}$ at 28 days.

\section{Deformation results}

Results of the total strain (creep strain + shrinkage strain) for all sets of loaded specimens are presented in Figure 1. Analysing Figure 1, it is noted that, roughly speaking, the total strain is similar for all specimens loaded at $30 \%$ of the stress-to-strength ratio (the maximum difference was $\sim 150 \times 10^{-6}$ ). Therefore,

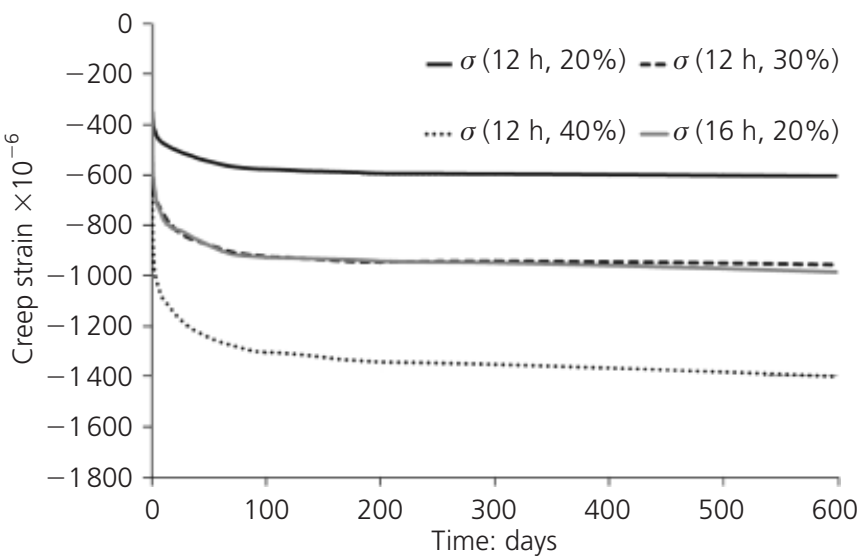

(a)

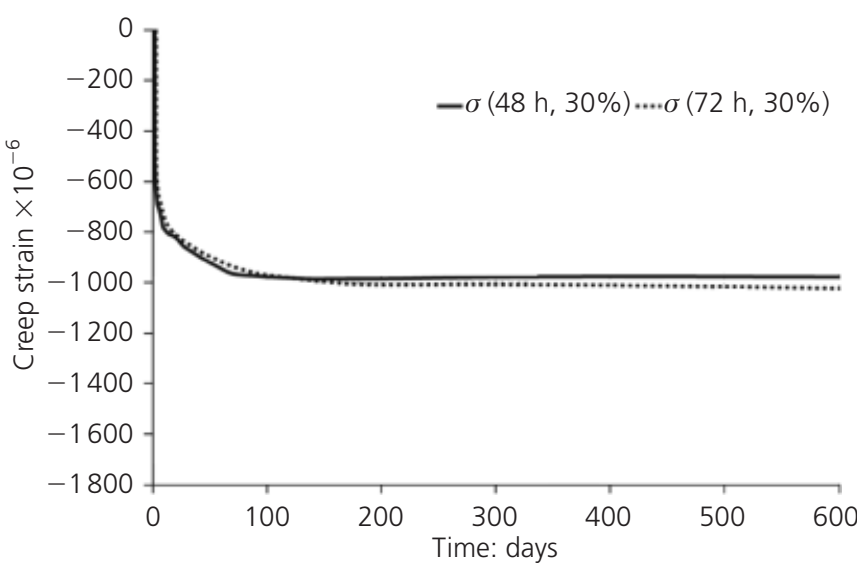

(c)

Figure 1. (a) Creep strain for all specimens loaded at $12 \mathrm{~h}$ and $16 \mathrm{~h}$, (b) creep strain for all specimens loaded at $20 \mathrm{~h}$ and $24 \mathrm{~h}$,

(c) creep strain for all specimens loaded at $48 \mathrm{~h}$ and $72 \mathrm{~h}$,

(d) total strain for all specimens
Age Elastic modulus: GPa Compressive strength: MPa

\begin{tabular}{lcc}
\hline $12 \mathrm{~h}$ & $35 \cdot 6$ & $48 \cdot 4$ \\
$16 \mathrm{~h}$ & - & $55 \cdot 2$ \\
$20 \mathrm{~h}$ & - & $59 \cdot 9$ \\
$24 \mathrm{~h}$ & $39 \cdot 9$ & $62 \cdot 3$ \\
$48 \mathrm{~h}$ & - & $66 \cdot 3$ \\
$72 \mathrm{~h}$ & - & $69 \cdot 3$ \\
$28 \mathrm{~d}$ & $45 \cdot 5$ & 91.9
\end{tabular}

Table 8. Evolution of mechanic properties measured

one may conclude that the resistance against the deformation increases with strength (note that to keep the stress-to-strength ratio constant, higher loads are applied for higher strengths).

Comparing the total strain of specimens loaded at the age of $12 \mathrm{~h}$ with those loaded at the age of $24 \mathrm{~h}$, it was observed that those loaded at the age of $24 \mathrm{~h}$ showed higher strain - such a difference

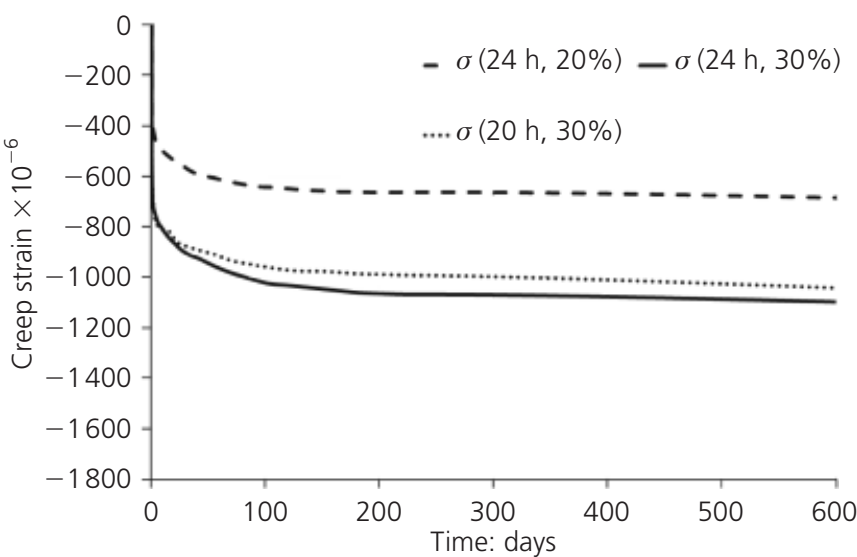

(b)

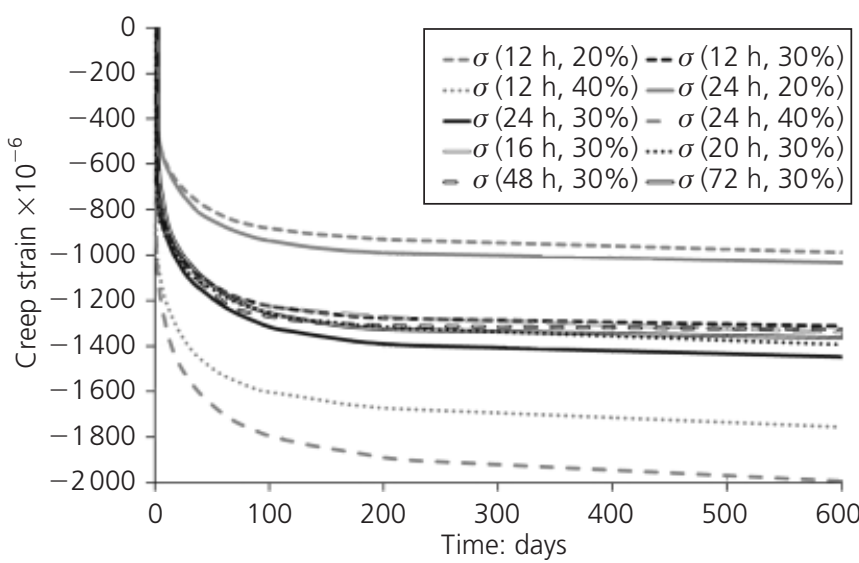

(d) 
being higher for greater loads. Thus, one may conclude that, from the age of $12 \mathrm{~h}$ to the age of $24 \mathrm{~h}$, the increase of resistance against the concrete deformation is lower than the increase of strength. Furthermore, looking at specimens loaded at the same age, but with different stress-to-strength ratios, it is observed that there is a near linear increase of strain; that is, the total strain of the specimens loaded at the age of $24 \mathrm{~h}$ varies (at the age of 600 days) from approximately $1030 \times 10^{-6}$ to $1450 \times 10^{-6}$ and then to $2000 \times 10^{-6}$ when the stress-to-strength ratio varies from $20 \%$ to $30 \%$ and to $40 \%$. Analogous trends can be observed for specimens loaded at the age of $12 \mathrm{~h}$.

Regarding the shrinkage strain, Figure 2 presents evolution curves for the deformation of non-loaded specimens. Analysing the measured curves, one observes a rapid evolution for approximately 200 days. However, after that age, the shrinkage increases by only about $10 \%$. According to the results shown in Figure 2, generally speaking, a consistent tendency relative to the age of demoulding (as previously reported in Bissonnette and Pigeon (1995) and as suggested by several models) is not observed. In fact, the specimens demoulded at the age of $12 \mathrm{~h}$ and at the age of $72 \mathrm{~h}$ are the ones with the lowest shrinkage, while the ones demoulded at the age of $16 \mathrm{~h}$ are the ones with the highest.

\section{Predictability and discussion of the proposed models}

Proposed creep and shrinkage models are useable for lower and higher $\mathrm{c} / \mathrm{p}$, and are adjusted to the normal and HSSCC. A nonlinear creep amplification function (Equation 3) is added to the creep model, which shows an influential stress function on the creep behaviour. The proposed creep model is adjusted to normal and HSSCC. Furthermore, SCC loading age parameter is included in the creep model as given by Equation 5 .

However, before analysing the predictability of the proposed models, it is important to remember that although shrinkage and creep are not totally independent phenomena (Bažant et al., 1994; Neville et al., 1983; Reinhardt and Rinder, 2006), in this experimental programme the total strain was roughly understood as



Figure 2. Shrinkage evolution



(a)

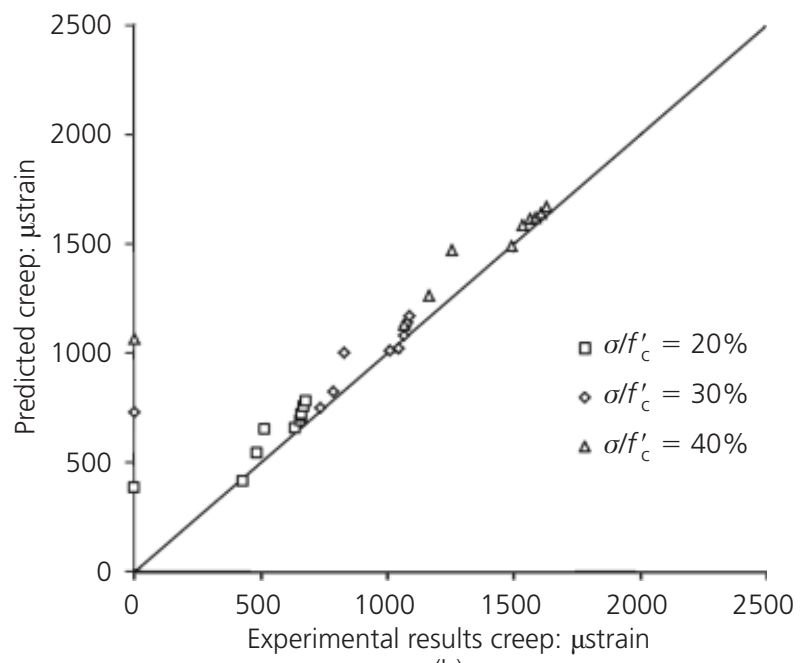

(b)

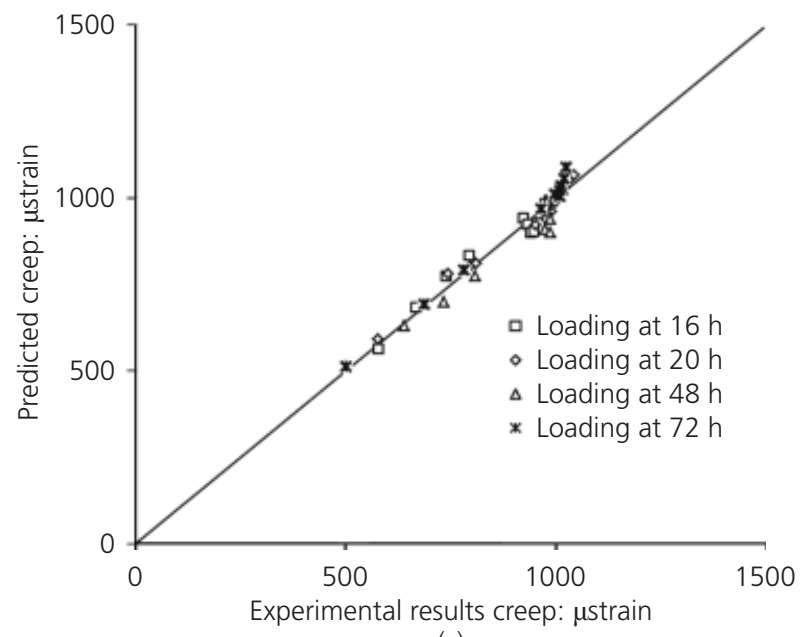

(c)

Figure 3. Comparison of the self-compacting concrete creep from experimental results versus calculated values from proposed model for (a) $12 \mathrm{~h}$ with different loading percentages, (b) $24 \mathrm{~h}$ with different loading percentages and (c) $30 \%$ loading rate for $16,20,48$, and $72 \mathrm{~h}$ 


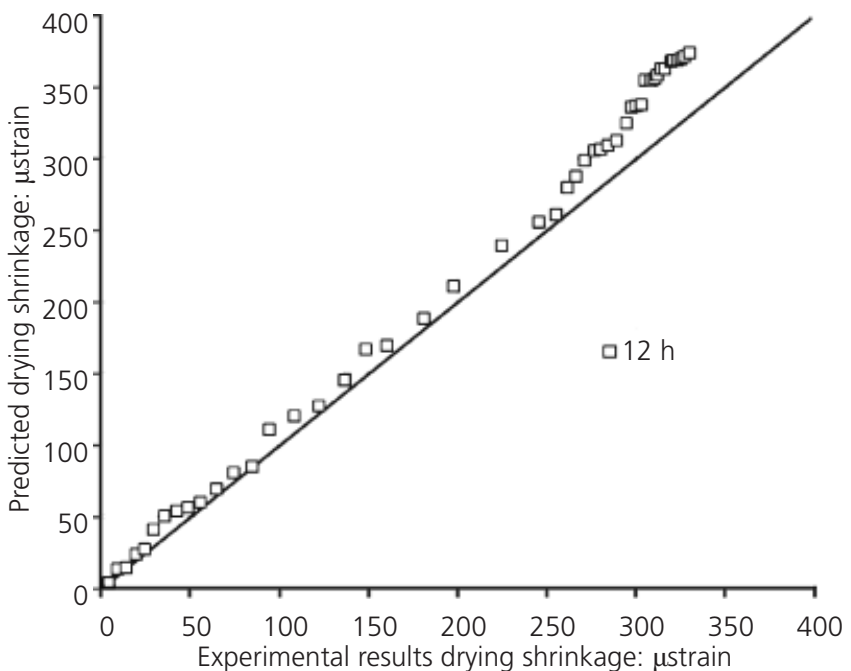

(a)

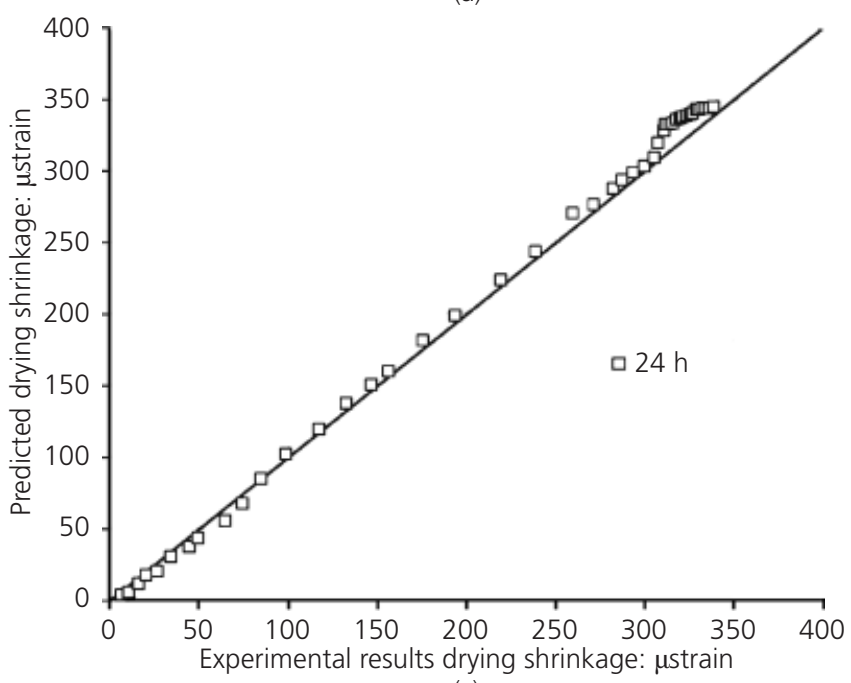

(c)

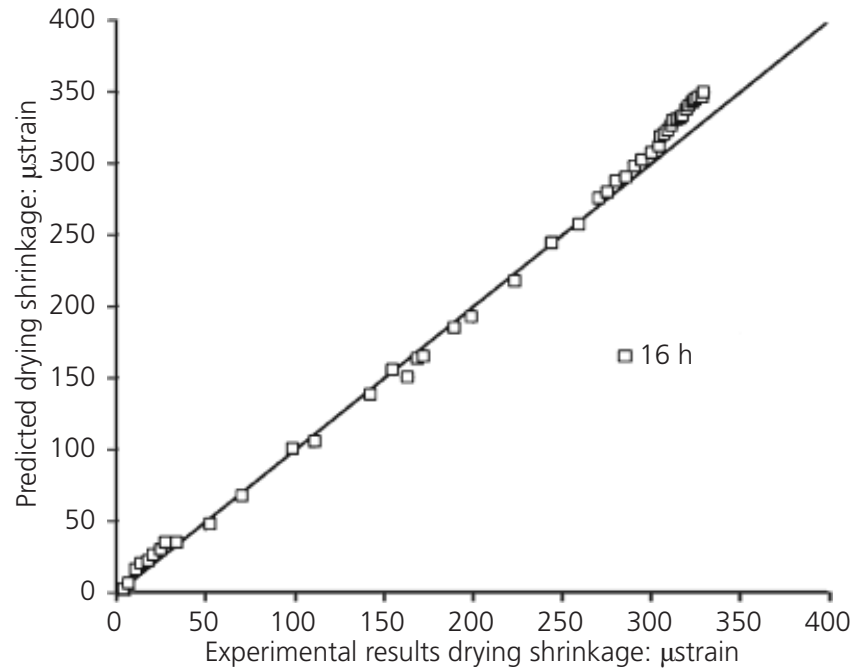

(b)

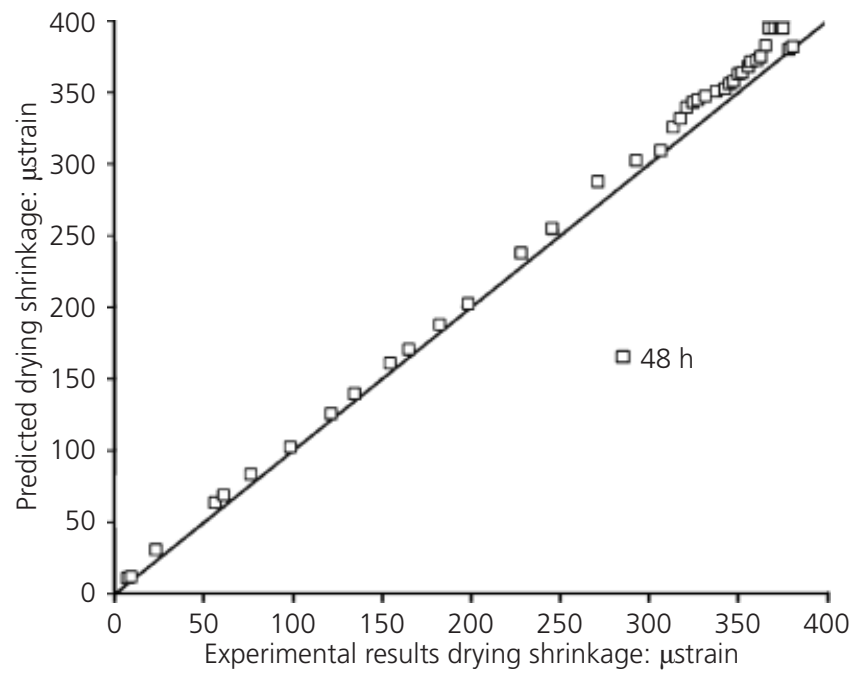

(d)

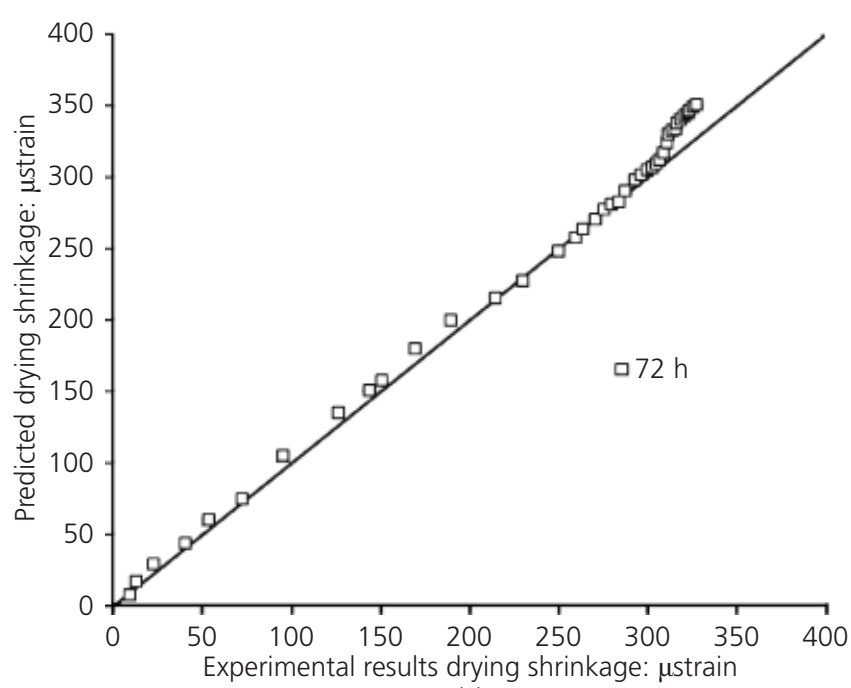

(e)

Figure 4. Comparison of the self-compacting concrete drying shrinkage from experimental results versus calculated values from proposed model for (a) $12 \mathrm{~h}$, (b) $16 \mathrm{~h}$, (c) $24 \mathrm{~h}$, (d) $48 \mathrm{~h}$ and (e) $72 \mathrm{~h}$ 
composed of the addition of these independent phenomena. Consequently, experimental results of creep strain used to verify the predictability of the proposed creep model were determined as the difference between the total strain and shrinkage strain (CEBFIB, 2012; Leemann et al., 2011; Reinhardt and Rinder, 2006). Besides, according to the experimental data reported above, the following parameters were considered in the predictability of the proposed models: $\mathrm{RH}=50 \%, w=128 \mathrm{~kg} / \mathrm{m}^{3}, \quad c=400 \mathrm{~kg} / \mathrm{m}^{3}$, $w / c=0 \cdot 32, v / s=141 \mathrm{~mm}, c / p=67.6 \%$ and $f_{\mathrm{cd}, 28 \mathrm{~d}}^{\prime}=91.9 \mathrm{MPa}$.

Figure 3 shows a comparison of the proposed creep model with the available experimental results of creep. In analysing Figure 3 one observes that the proposed model provides an accurate prediction. In fact, most of the creep results predicted by the proposed model were slightly overestimated, but always with a difference lower than $10 \%$ to the experimental results.

Figure 3 shows a comparison of the SCC creep from experimental results plotted against calculated values from the proposed model for (a) loading at the age of $12 \mathrm{~h}$ with different levels of the stress-to-strength ratios loading percentages, (b) loading at the age of $24 \mathrm{~h}$ with different levels of the stress-to-strength ratios loading percentages, and (c) $30 \%$ loading at the age of loading rate for $16,20,48$ and $72 \mathrm{~h}$ with a level of $30 \%$ of the stress-tostrength ratio. Based on the results and comparisons reported in Figure 3, the proposed creep model was accurate for different levels of stress and different ages at loading time. In fact, most of the creep results predicted by the proposed model were slightly overestimated, but always with the difference being lower than $10 \%$ of the experimental results.

In terms of the proposed shrinkage model, Figure 4 shows a comparison of the SCC shrinkage from experimental results against calculated values from the proposed model for (a) $12 \mathrm{~h}$, (b) $16 \mathrm{~h}$, (c) $24 \mathrm{~h} \mathrm{(d)} 48 \mathrm{~h}$ and (e) $72 \mathrm{~h}$. Looking at Figure 4, roughly speaking, it can be noted that the proposed model provided a good prediction (especially up to the age of 100 days). The predicted results were mostly conservative (especially after the age of 300 days), the maximum difference $(\sim 20 \%)$ between predicted and experimental results occurring when specimens were demoulded at the age of $12 \mathrm{~h}$ (Figure 4(a)).

\section{Conclusions}

The predictability of deformation models have been investigated for CC and SCC in this paper. Two new models are proposed for an accurate prediction of creep and shrinkage for concrete structures made with HSSCC. Based on comparisons between different models and on comparisons to the experimental results, some conclusions can be drawn from this study.

- For the CC mixtures the AASHTO (2007) and JSCE (2002) models provided better predictions of the creep and shrinkage data compared with the other models. Although the BSI (2004) and AASHTO (2004) models had provided suitable predictions for creep, they were not so successful for shrinkage.

- For the SCC mixtures the JSCE (2002) model provided better predictions of the creep and shrinkage data than the other models because of the certain intrinsic and/or extrinsic variables. The AASHTO (2004) and ACI (1992) CC models also provided suitable predictions for creep, and the AASHTO (2007) and AS (2009) CC models also provided suitable predictions for shrinkage.

- The proposed creep and shrinkage models have good predictions for high strength of the SCC mixtures. The comparison between the predicted values and the experimental results conducted in this study showed that the proposed models were able to predict creep and shrinkage with an accuracy of $10 \%$ and $20 \%$ respectively.

\section{Acknowledgements}

Funding provided by the Portuguese Foundation for Science and Project Technology (FCT) and the European Social Fund (ESF), namely for the Research Unit 'LABEST, Laboratory for the Concrete Technology and Structural Behavior, is gratefully acknowledged.

\section{REFERENCES}

AASHTO (American Association of Highway and Transportation Officials) (2004) Bridge design Specifications and Commentary. AASHTO, Washington, DC, USA.

AASHTO (2007) Interim Bridge Design Specifications and Commentary. AASHTO, Washington, DC.

ACI (American Concrete Institute) (1992) ACI 209R-92: Prediction of creep, shrinkage, and temperature effects in concrete structures. ACI, Farmington Hills, MI, USA.

AS (Standards Australia) (2009) AS 3600: Concrete structures. AS, Sydney, Australia.

Aslani F and Nejadi S (2011a) Comparison of creep prediction models for self-compacting and conventional concrete. In Proceedings of 9th International Symposium on High Performance Concrete, Rotorua, New Zealand (Khrapko M and Wallevik O (eds)). New Zealand Concrete Society, Auckland, New Zealand, pp. 1-10.

Aslani F and Nejadi S (2011b) Comparison of shrinkage prediction models for self-compacting and conventional concrete. In Proceedings of 9th International Symposium on High Performance Concrete, Rotorua, New Zealand, August 2011 (Khrapko M and Wallevik O (eds)). New Zealand Concrete Society, Auckland, New Zealand, pp. 1-10.

Aslani F and Nejadi S (2012a) Mechanical properties of conventional and self-compacting concrete: An analytical study. Construction Building Materials 36: 330-347.

Aslani F and Nejadi S (2012b) Shrinkage behavior of selfcompacting concrete. Journal of Zhejiang University Science A 13(6): 407-419.

ASTM (2002) ASTM C 469: Standard test method for static modulus of elasticity and Poisson's ratio of concrete in compression. ASTM International, Philadelphia, PA, USA. 
Bažant Z, Huet C and Müller H (1994) Comment on recent analysis of concrete creep linearity and applicability of principle of superposition. Materials and Structures 27(6) 359-61.

Bhattacharya A (2008) Effects of Aggregate Grading and Admixtures/Fillers on Fresh and Hardened Properties of SelfConsolidating Concrete. MSc thesis, West Virginia University, USA.

Bissonnette B and Pigeon M (1995) Tensile creep at early ages of ordinary, silica fume and fiber reinforced concretes. Cement and Concrete Research 25(5): 1075-1085.

BSI (2000a) BS EN 197-1:2000: Cement - Part 1: Composition, specifications and conformity criteria for common cements. BSI, London, UK.

BSI (2000b) BS EN 1097-6:2000: Tests for mechanical and physical properties of aggregates. Determination of particle density and water absorption. BSI, London, UK.

BSI (2004) BS EN 1992-1-2:2004: Eurocode 2: Design of concrete structures. Part 1.2: General rules-structural fire design. BSI, London, UK.

CEB-FIB (2012) Model Code 2010 - Final Draft. FIB, Laussanne, Switzerland, FIB bulletin no, 65, vol. 1.

Chopin D, Francy O, Lebourgeois S and Rougeau P (2003) Creep and shrinkage of heat-cured self-compacting concrete (SCC). Proceedings of 3rd International Symposium on SelfCompacting Concrete, Reykjavik, Iceland, pp. 672-683.

Cordoba B (2007) Creep and Shrinkage of Self-Consolidating Concrete (SCC). MSc thesis, University of Wyoming, WY, USA.

EFNARC (Experts for Specialised Construction and Concrete Systems) (2005) The European Guidelines for Selfcompacting Concrete. See http://www.efnarc.org/pdf/ SCCGuidelinesMay2005.pdf (accessed 28/06/2013).

Güneyisi E, Gesoğlu M and Özbay E (2010) Strength and drying shrinkage properties of self-compacting concretes incorporating multi-system blended mineral admixtures. Construction and Building Materials 24(10): 1878-1887.

Heirman G, Vandewalle L, Van Gemerta D et al. (2008) Timedependent deformations of limestone powder type selfcompacting concrete. Engineering Structures 3(10): 29452956.

Horta A (2005) Evaluation of Self-Consolidating Concrete for Bridge Structures Applications. MSc thesis, Georgia Institute of Technology, Atlanta, GA, USA.

Hwang SD and Khayat K (2010) Effect of mix design on restrained shrinkage of self-consolidating concrete. Materials and Structures 43(3): 367-380.

Issa M, Alhassan M, Shabila H and Krozel J (2005) Laboratory performance evaluation of self-consolidating concrete. Proceeding of the Second North American Conference on the Design and Use of Self Consolidating Concrete and the Fourth International RILEM Symposium on SelfConsolidating Concrete, Center for Advanced Cement-Based Materials (ACBM), Chicago, USA, pp. 857-862. JSCE (Japanese Society of Civil Engineers) (2002) Standard specifications for concrete structure - 2002. JSCE, Tokyo, Japan.

Khayat KH and Long WJ (2010) Shrinkage of precast, prestressed self-consolidating concrete. ACI Materials Journal 107(3): 231-238.

Kim YH (2008) Characterization of Self-consolidating Concrete for the Design of Precast, Pretensioned Bridge Superstructure Elements. PhD thesis, Texas A\&M University, TX, USA.

Klug Y and Holschemaker K (2003) Comparison of the hardened properties of self-compacting and normal vibrated concrete. Proceedings of 3rd RILEM Symposium on Self Compacting Concrete, Reykjavik, Iceland, pp. 596-605.

Landsberger GA and Fernandez-Gomez J (2007) Evaluation of creep prediction models for self-consolidating concrete. Proceedings of 5th RILEM Symposium on SCC, Pro 54, Ghent, Austria, vol. 2, pp. 605-610.

Larson K (2006) Evaluation the Time-Dependent Deformation and Bond Characteristics of a Self-Consolidating Concrete Mix and the Implication for Pretensioned Bridge Applications. PhD thesis, Kansas State University, Manhattan, KS, USA.

Leemann A, Lura P and Loser R (2011) Shrinkage and creep of $\mathrm{SCC}$ - the influence of paste volume and binder composition. Construction and Building Materials 25(5): 2283-2289.

Loser R and Leemann A (2009) Shrinkage and restrained shrinkage cracking of self-compacting concrete compared to conventionally vibrated concrete. Materials and Structures 42(1): $71-82$.

Ma K, Xie Y, Long G and Luo Y (2009) Drying shrinkage of medium strength SCC. Proceedings of Second International Symposium on Design, Performance and Use of SelfConsolidating Concrete SCC'2099, China, pp. 657-663.

Mazzotti C, Savoia M and Ceccoli C (2006) Creep and Shrinkage of Self Compacting Concrete. Proceedings of $2 \mathrm{nd}$ fib Conference, Naples, pp. 1-10 (on CD).

Mazzotti C and Ceccoli C (2009) Creep and shrinkage of self-compacting concrete: Experimental behavior and numerical model. In Proceedings of the Eighth International Conference on Creep, Shrinkage and Durability Mechanics of Concrete and Concrete Structures, Ise-Shima, Japan (Tanabe T-A, Sakata K, Mihashi H et al. (eds)). CRC Press, Boca Raton, FL, USA, pp. 667-673.

Naito CJ, Parent G and Brunn G (2006) Performance of bulb-tee girders made with self-consolidating concrete. PCI Journal 51(6): $72-85$.

Neville AM (1996) Properties of Concrete, 4th edn. Wiley, New York, NY, USA.

Neville AM, Dilger WH and Brooks JJ (1983) Creep of Plain and Structural Concrete. Construction Press, London New York.

Oliva MG and Cramer S (2008) Self-Consolidating Concrete: Creep and Shrinkage Characteristics. Report. University of Wisconsin, Madison, WI, USA.

Ouchi M, Nakamura S, Osterson T, Hallberg S and Lwin M (2003) Applications of Self-Compacting Concrete in Japan. ISHPC, Europe and the United States, pp. 1-20. 
Persson B (2001) A comparison between mechanical properties of SCC and the corresponding properties of normal concrete. Cement and Concrete Research 31(2): 193-198.

Persson B (2005) Creep of self-compacting concrete. Proceedings of International Conference CONCREEP 7, Nantes, France, pp. 535-540.

Poppe AM and De Schutter G (2001) Creep and shrinkage of self-compacting concrete. Proceedings of the Sixth International Conference CONCREEP 6, pp. 563-568.

Poppe AM and De Schutter G (2005) Creep and shrinkage of self-compacting concrete. First International Symposium on Design, Performance and Use of Self-Consolidating Concrete, China. pp. 329-336.

Reinhardt H-W and Rinder T (2006) Tensile creep of highstrength concrete. Journal of Advanced Concrete Technology 4(2): 277-283.

Schindler AK, Barnes RW, Roberts JB and Rodriguez S (2007) Properties of self-consolidating concrete for prestressed members. ACI Material Journal 104(1): 53-61.

Seng V and Shima H (2005) Creep and shrinkage of selfcompacting concrete with different limestone powder contents. in Proceedings of 4th RILEM Symposium on Self-Compacting Concrete, Chicago, IL, USA, pp. 981987.

Suksawang N, Nassif HH and Najim HS (2006) Evaluation of mechanical properties for self-consolidating, normal, and high-performance concrete. Transportation Research Record 1979: $36-45$.

Turcry P, Loukili A, Haidar K, Pijaudier-Cabot G and Belarbi A (2006) cracking tendency of self-compacting concrete subjected to restrained shrinkage: experimental study and modelling. ASCE, Journal of Materials in Civil Engineering 18(1): 46-54.

Vidal T, Assié S and Pons G (2005) Creep and shrinkage of selfcompacting concrete and comparative study with model code. In Proceedings of International Conference CONCREEP 7, Nantes, France, pp. 541-546.

Zheng J, Chao P and Luo S (2009) Experimental study on factors influencing creep of self-compacting concrete. Proceedings of Second International Symposium on Design, Performance and Use of Self-Consolidating Concrete, SCC'2009, China, pp. 703-709.

\section{WHAT DO YOU THINK?}

To discuss this paper, please submit up to 500 words to the editor at www.editorialmanager.com/macr by 1 March 2014. Your contribution will be forwarded to the author(s) for a reply and, if considered appropriate by the editorial panel, will be published as a discussion in a future issue of the journal. 